\title{
Family planning and reproductive health: the link to environmental preservation
}

\author{
J. Joseph Speidel · Deborah C. Weiss • \\ Sally A. Ethelston · Sarah M. Gilbert
}

Published online: 14 April 2007

(C) Springer Science+Business Media B.V. 2007

\begin{abstract}
This paper seeks to refocus the attention of environmentalists on the importance of population trends to environmental sustainability and identifies prevention of unintended pregnancy as potential common ground for environmentalists and family planning advocates. The health and other welfare benefits of preventing unintended pregnancy are felt most keenly by individual women, men, and their families. At the same time, however, preventing unwanted pregnancies usually results in smaller family size, an important factor in slowing population growth and, as a result, a source of broader benefits-including environmental benefits-to society.
\end{abstract}

Keywords Population - Environment - Family planning - Reproductive health · Unintended pregnancy $\cdot$ HIV/AIDS

\section{Population-environment interactions: population growth, consumption, and human impact}

As much as half of the Earth's total biological productivity has already been diverted to human use, depleting our natural resources and impairing the capacity of life-supporting ecosystems (Brown, 2004; Ehrlich, 1990; Green, 1992; Millennium Ecosystem Assessment, 2005; United Nations Development Programme, United Nations Environment Programme, World Bank, World Resources Institute, 2002; Wilson, 2002; World Resources Institute, 1998). Continued growth in the world's population will add to this environmental burden and, in places where growth is proceeding rapidly, will undermine the prospects for socioeconomic development (Kendall, 2005; Population Summit of the World's Scientific Academies, 1993;

J. J. Speidel $(\bowtie) \cdot$ D. C. Weiss · S. A. Ethelston · S. M. Gilbert

Bixby Center for Reproductive Health Research \& Policy, University of California, San Francisco, 3333 California Street, Suite 335, Box 0744, San Francisco, CA 94143-0744, USA

e-mail: speidelj@obgyn.ucsf.edu

URL: http://crhrp.ucsf.edu/publications/internal.html 
Wilson, 2002). The United Nations (UN) medium-variant population projection suggests that between 2000 and 2050, the world will have to accommodate 3 billion additional people and support desperately needed advances in living standards for nearly 3 billion people living in poverty (Population Division of the Department of Economic and Social Affairs of the United Nations Secretariat, 2005; World Bank, 2005).

The impact of humans on their environment is related to population size, per capita consumption, and the environmental impact of the technology used to produce what is consumed. Between 1950 and 2000, the world's population more than doubled, from 2.5 to 6.1 billion (Population Division of the Department of Economic and Social Affairs of the United Nations Secretariat, 2005). At the same time, the gross world product expanded nearly seven-fold, from approximately $\$ 7$ to $\$ 46$ trillion of annual output (Assadourian, 2003). Continued modest growth in per capita consumption, at a rate of just $2 \%$ annually, would result in a four-fold increase in per capita consumption by 2075 . Combined with a projected $52 \%$ increase in population size over the same period, this level of consumption could require economic production to increase six-fold (Population Division, Department of Economic and Social Affairs, United Nations, 2004). To achieve this without further degradation of important ecosystems presents a daunting challenge.

The recent UN-sponsored Millennium Ecosystem Assessment, which was conducted by more than 1,300 experts in 95 countries, examined the effects of ecosystem change on human health and well-being (Millennium Ecosystem Assessment, 2005). It found that humans have changed ecosystems more rapidly and extensively over the past 50 years than during any other period, primarily to meet increasing demands for food, fresh water, timber, fiber, and fuel. The Millennium Ecosystem Assessment estimated that $60 \%$ of ecosystem services-the benefits people obtain from ecosystems - are being degraded or used unsustainably (Millennium Ecosystem Assessment, 2005).

World population growth

\section{The numbers}

In 1950, the world's population was 2.5 billion, the average number of children per woman (total fertility rate or TFR) ${ }^{1}$ was 5.3 , and annual population growth was 48 million (Population Division of the Department of Economic and Social Affairs of the United Nations Secretariat, 2005). Since then, the TFR has decreased to 2.7, but death rates have also declined, and total world population has increased to 6.5 billion (see Fig. 1) (Population Division of the Department of Economic and Social Affairs of the United Nations Secretariat, 2005). Presently, 76 million people are added to the world's population each year.

The UN medium-variant projection suggests a further decline in the TFR worldwide to 2.1 by 2050 , although population will increase to 9.1 billion (Population Division of the Department of Economic and Social Affairs of the

\footnotetext{
1 The total fertility rate or TFR is the average number of children a woman has over her lifetime.
} 


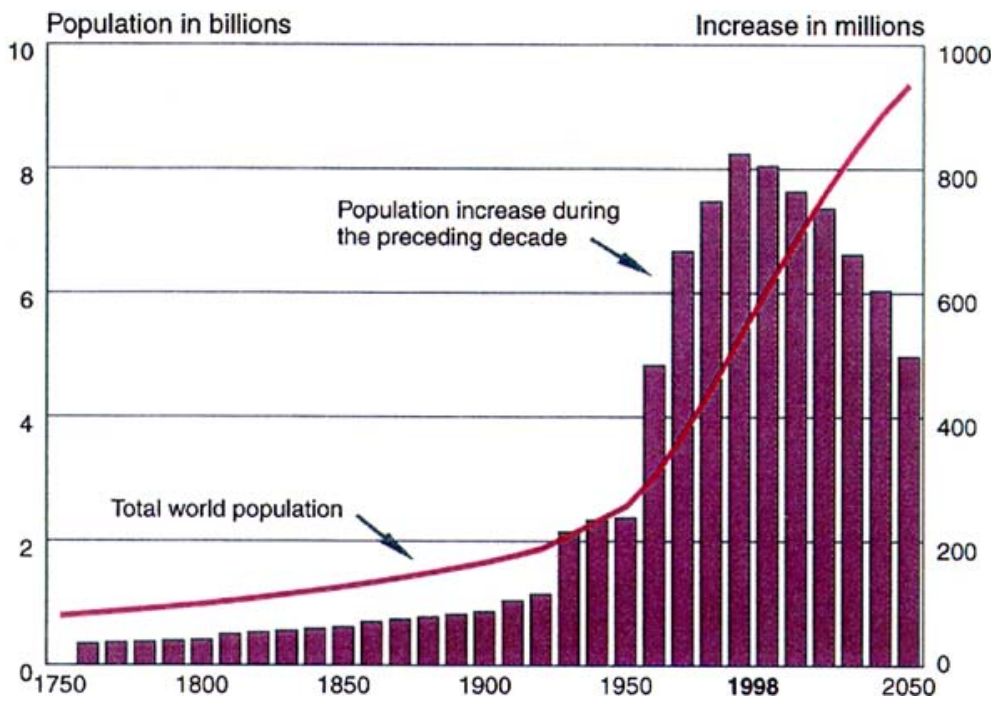

Fig. 1 Estimated world population growth: 1750-2050 (McDevitt, 2005). Source: (McDevitt, 2005)

United Nations Secretariat, 2005). Developing countries currently account for $95 \%$ of world population growth (United Nations, Department of Economic and Social Affairs, Population Division, 2005a).

Despite projected declines in fertility, the annual number of births worldwide is expected to remain high (McDevitt, 2005). Previously high fertility rates have left many poor countries with large numbers of women of reproductive age; their numbers are projected to increase from 1.6 to 2.1 billion between 2005 and 2050 (Population Division of the Department of Economic and Social Affairs of the United Nations Secretariat, 2005). As these women have children, population size will increase even as fertility rates decline, a phenomenon known as population momentum. For example, although China's TFR has fallen below the replacement level of 2.1, the large number of couples of reproductive age has kept the country's population growing by about 8 million annually (Population Reference Bureau, 2007b).

High-fertility still persists in much of the developing world, ensuring that population growth will continue. In 2006, average family size among the 4 billion people living in less developed countries outside of China was estimated at 3.4 children, with an annual population growth rate of $1.8 \%$ (Population Reference Bureau, 2007b). At this rate, the population of these countries would double in just 39 years. Even taking projected declines in fertility in these regions into account, the number of people living in less developed countries outside China is projected to increase by more than $60 \%$ by 2050 , from 4 billion today to more than 6.5 billion (Population Reference Bureau, 2007b).

\section{Sources of world population growth}

Contrary to what some people may think, future population growth will not be due primarily to the desire for large families. In 1994, Bongaarts estimated that most of 
the projected population increase in developing countries will result from population momentum (49\%), followed by unwanted pregnancies $(33 \%)$, and high desired family size (18\%) (Bongaarts, 1994).

The significance of unwanted pregnancies for population growth can be seen in the high proportion of pregnancies that are unplanned each year: out of 210 million pregnancies worldwide, 80 million (38\%) are unplanned, and 46 million (22\% of all pregnancies) end in abortion (Alan Guttmacher Institute, 1999).

Yet reducing unintended pregnancy is the factor in continued population growth that is most amenable to program and policy intervention. Organized family planning programs have a 40-year track record of success in helping hundreds of millions of couples choose the number and timing of their pregnancies. Indeed, surveys show that more than 200 million women in developing countries who would like to delay their next pregnancy, or stop bearing children altogether, must rely on traditional, less effective methods of contraception (64 million) or are using no method because they lack access or face other barriers to using contraception (137 million) (Singh, Darroch, Vlassoff, \& Nadeau, 2003). These barriers include cultural values that support high fertility, opposition to use of contraception by family members, and fears about health risks or side effects of contraception (Carr \& Khan, 2004).

\section{U.S. population growth}

\section{The numbers}

The high levels of consumption and large population of the United States have a disproportionate environmental impact. In contrast to almost all other developed countries, the United States is experiencing relatively rapid population growth (Perry \& Mackun, 2005). Now the world's third-largest country, it is projected to grow from 300 million in 2006 to nearly 350 million in 2025, and to 420 million by 2050 (Population Reference Bureau, 2007b).

\section{Sources of U.S. population growth}

Natural increase (births exceeding deaths) accounts for $60 \%$ of population growth in the United States, with 4.1 million births and 2.4 million deaths in 2003; immigration accounts for the remaining $40 \%$ of annual growth (Kent \& Mather, 2002; Munson \& Sutton, 2004).

Unintended pregnancy is a major contributing factor to the relatively high birth rate in the United States. Of 6.4 million pregnancies in 2001-the most recent year for which data is available-almost half (3.1 million) were unintended (as were $82 \%$ of the 811,000 annual teen pregnancies), resulting in 1.1 million miscarriages, 1.3 million abortions, and of a total of 4 million births, 1.4 million were unintended (Finer \& Henshaw, 2006). Without these 1.4 million unintended births, the natural increase of the U.S. population would be about 300,000 per year, less than 20 percent of what it is today. In other words, unintended pregnancy can be said to 
account for roughly half of the current increase of 2.9 million people to the U.S. population each year (U.S. Census Bureau, Population Division, 2007)

The contribution of immigration to U.S. population growth is also important. Between 2000 and 2004, 4.3 million immigrants, including an estimated 2 million illegal immigrants, arrived in the country (Camarota, 2004). Migration expert Jeffrey Passel estimates there are 11.5-12 million undocumented immigrants in the United States (Passel, 2006). There is also an important relationship between immigration and natural increase: nearly one-quarter of babies born in 2002 had a foreign-born mother, an increase from 6\% in 1970 (Camarota, 2005).

\section{Facing the challenges of rapid population growth: politics and policy}

Placing a priority on family planning

Provision of family planning services is the most direct intervention to slow population growth and assist environmental preservation (Kent \& Mather, 2002). According to Dr. Malcolm Potts: "All societies with unconstrained access to fertility regulation, including abortion, experience a rapid decline to replacement levels of fertility, and often lower' (Potts, 1997). Better contraceptives and the establishment of organized family planning programs have successfully met the demand for small families and decreased fertility:

- Between 1960 and 2005, contraceptive prevalence in less developed countries increased from 9\% (30 million users) to 58\% (550 million users) among married women of reproductive age (Population Division of the Department of Economic and Social Affairs of the United Nations Secretariat, 2005; Population Reference Bureau, 2005, 2007a, b; United Nations Department of Economic and Social Affairs Population Division 2005).

- During the same time period, the TFR in developing countries declined by half, from 6.0 to 3.1 (Population Division of the Department of Economic and Social Affairs of the United Nations Secretariat, 2005).

The importance of abortion in allowing childbearing choices is seldom recognized. Given the high unmet need for family planning and the high failure rates of existing methods of contraception, access to safe abortion is necessary for women to fully control their fertility.

The impact of organized family planning programs on population growth is clear: such programs were responsible for at least $40 \%$ of the fertility decline in developing countries from the 1960s through the end of the 1980s (Vlassoff, Singh, Darroch, Carbone, \& Bernstein, 2004). At the same time, fewer pregnancies, appropriately spaced, means less exposure to the risks associated with pregnancy and childbirth. Indeed, use of family planning could prevent at least one-quarter of maternal deaths in developing countries (Levine et al., 2006).

The experiences of Thailand, Iran, and California demonstrate how publicly supported family planning programs can successfully curb population growth. 
Thailand's government launched its population program in 1970, making available a broad array of contraceptives distributed by nurses, midwives, and within communities (Rosenfield, 1971). By the late 1980s, Thailand's TFR had dropped below replacement-level to fewer than two births per woman (compared with about seven births per woman just two decades earlier) and currently remains low at 1.7 (Hirschman, Tan, Chamratrithirong, \& Guest, 1994; Population Reference Bureau, 2007b).

As described elsewhere in this journal, the Iranian government, with the support of Muslim religious leaders, restored its national family planning program in 1989 . Subsequently, the TFR dropped from 5.5 in 1988 to 2.8 in 1996 and is currently at the replacement-level of 2.0 births per woman (Abbasi-Shavazi, 2002; Population Reference Bureau, 2007b).

Low-income women represent $38 \%$ of California's women of reproductive age and account for nearly two-thirds of births in the state (Braveman, Egerter, \& Marchi, 1999; State of California, Department of Finance, Demographic Research Unit, 1999). The Family PACT (Planning, Access, Care and Treatment) Program provides family planning and reproductive health services at no cost to low-income residents with the following results:

- During the program's first 5 years, the number of clients served more than doubled-from 750,000 to 1.55 million (Bixby Center for Reproductive Health Research \& Policy, 2005).

- The contraceptive services provided by Family PACT in 2002 averted an estimated 205,000 unintended pregnancies (Foster et al., 2006). Every dollar spent on Family PACT avoided public expenditures-for medical care, income support, and social services for women and their children - that would have cost $\$ 2.76$ over 2 years and $\$ 5.33$ over 5 years (Brindis, Amaral, Foster, \& Biggs, 2005). An investment of $\$ 403.8$ million in 2002 therefore saved $\$ 1.1$ billion over 2 years and will save $\$ 2.2$ billion over 5 years.

The experience from these diverse settings shows that impressive declines in fertility and population growth are possible in a short period of time through implementation of well-managed, fully voluntary family planning programs that meet the needs of individuals and families. Similar programs could — at relatively low cost-yield a substantial impact on population growth worldwide and help to alleviate the increasing burden it places on the environment.

\section{Meeting the growing need for resources}

\section{International challenges}

Increased financial resources will be needed not only to maintain contraceptive use at current levels, but also to meet growing demands for family planning. Even if the proportion of couples using contraceptives were to remain level between 2000 and 2015, developing countries would still have to serve 125 million additional couples (Ethelston, Bechtel, Chaya, Kantner, \& Vogel, 2004). 
However, the global community has failed to provide the funds needed to meet the current unmet demand for family planning, let alone fulfill the 1994 International Conference on Population and Development (ICPD) goal of universal access to this and other basic reproductive health services. The ICPD estimated the cost of a limited array of programs for family planning, safe childbirth, and STI/ HIV/AIDS prevention at $\$ 18.5$ billion by 2005 ( $\$ 25$ billion when adjusted for inflation), of which two-thirds was to come from developing countries and one-third from donor countries (UNFPA, 2005). Revised cost estimates, by Speidel and UNAIDS, call for $\$ 14$ billion in annual spending for family planning, $\$ 15$ billion for reproductive health, and $\$ 14.9$ billion for the full range of HIV/AIDS prevention, treatment, care, and support (Speidel, 2005; UNAIDS, 2005). These adjustments for inflation and the increased price tag for reproductive health and STI/HIV/AIDS bring the annual funding target for 2005 to $\$ 45.8$ billion, rather than the original $\$ 18.5$ billion.

Of this revised target of $\$ 45.8$ billion, donors would need to provide about $\$ 20$ billion and developing countries about \$25 billion (see Table 1) (Speidel, 2005). These targets can be compared to current estimates of $\$ 6.1$ billion provided by donors and $\$ 14.9$ billion by developing country governments and consumers in 2005 (van Dalen \& Reuser, 2005).

An analysis of donor funding by area of activity shows great divergence in the priority afforded to each. It is notable that most of the recent increase in donor outlays for population assistance has been for HIV/AIDS, while donor funds specifically allocated for family planning have decreased over the past decade.

Between 1995 and 2004, the most recent year with preliminary data (excluding loans): (UNFPA, UNAIDS, \& NIDI, 2004; United Nations, 2005).

- Funding for STI/HIV/AIDS activities increased from $9 \%$ of total population assistance to $54 \%$. Donor countries are expected to have spent almost two-thirds of their population assistance on STI/HIV/AIDS activities in 2005.

Table 12005 ICPD funding targets adjusted for inflation, broadened HIV/AIDS and reproductive health services compared to projected 2005 population assistance and domestic expenditures (in \$ billions and percents)

\begin{tabular}{lllll}
\hline & $\begin{array}{l}\text { 2005 Original ICPD } \\
\text { target (1993\$) }\end{array}$ & $\begin{array}{l}\text { Revised 2005 target adjusted } \\
\text { for inflation, HIV/AIDS and } \\
\text { reproductive health }(2005 \$)\end{array}$ & $\begin{array}{l}\text { 2005 Projected } \\
\text { expenditures }\end{array}$ & $\begin{array}{l}\% \text { of } \\
\text { revised } \\
\text { target }\end{array}$ \\
\hline $\begin{array}{c}\text { Donor share } \\
\text { (one-third) }\end{array}$ & $\$ 6.1$ & $\$ 20.2$ & $\$ 6.1$ & 30 \\
$\begin{array}{c}\text { Developing } \\
\text { country } \\
\text { share }\end{array}$ & $\$ 12.4$ & $\$ 25.6$ & $\$ 14.9$ & 58 \\
\begin{tabular}{l} 
Total \\
\hline
\end{tabular} & $\$ 18.5$ & $\$ 45.8$ & $\$ 21.0$ & 46 \\
\hline
\end{tabular}

Notes and Sources:

Donor targets were assumed to be one-third of totals needed except for adjusted STI/HIV/AIDS targets, where donor share is assumed to be two-thirds.

Adapted from: Speidel (2005). 
- Funding for basic reproductive health services increased, with fluctuations, from $18 \%$ in 1995 to $25 \%$ in 2004.

- Funding explicitly for family planning services decreased, with fluctuations, from a high of 55\% in 1995 to just $9 \%$ in 2004; however, some family planning is now funded from within the reproductive health category.

- Funding for family planning activities decreased in absolute dollar amounts from $\$ 723$ to $\$ 442$ million (a decrease of $39 \%$ ), while funds for STI/HIV/AIDS activities increased 22-fold.

If the revised targets for donor funding in 2005 are compared to the preliminary 2004 donor contributions, family planning assistance reached only $9 \%$ of the \$5 billion annual outlays needed. Reproductive health and HIV/AIDS fare slightly better, with donors providing about a quarter of the $\$ 5$ billion needed for reproductive health and a quarter of the $\$ 10$ billion needed for HIV/AIDS (see Table 2). Clearly, reproductive health, and especially family planning, is being neglected (Singh et al., 2003).

\section{U.S. challenges}

Public funding for family planning services in the United States is not keeping pace with demands. A recent study estimates the annual cost of family planning for each client at between $\$ 124$ and $\$ 487$ with a mid-range estimate of $\$ 203$ (Frost, Sonfield, Gold, \& Ahmed, 2006). California’s Family PACT Program annually spends \$236

Table 22005 ICPD funding targets for donors adjusted for inflation, broadened HIV/AIDS and reproductive health services compared to estimated 2004 donor population assistance by category targets (in $\$$ billions and percents)

\begin{tabular}{|c|c|c|c|c|c|}
\hline \multirow{2}{*}{$\begin{array}{l}\text { Expenditure } \\
\text { category }\end{array}$} & \multirow{2}{*}{$\begin{array}{l}2004 \\
\text { Donor } \\
\text { expenditures } \\
\text { estimated }\end{array}$} & \multicolumn{2}{|l|}{2005} & \multicolumn{2}{|l|}{2005} \\
\hline & & $\begin{array}{l}\text { Original ICPD } \\
\text { donor target } \\
(1993 \$)\end{array}$ & $\begin{array}{l}\% \text { of } \\
\text { target }\end{array}$ & $\begin{array}{l}\text { Revised donor target adjusted } \\
\text { for inflation, HIV/AIDS, \& } \\
\text { reproductive health (2005\$) }\end{array}$ & $\begin{array}{l}\% \text { of } \\
\text { target }\end{array}$ \\
\hline $\begin{array}{l}\text { Family } \\
\text { planning }\end{array}$ & $\$ 0.453$ & $\$ 3.8$ & 12 & $\$ 5.2$ & 9 \\
\hline $\begin{array}{l}\text { Reproductive } \\
\text { health }\end{array}$ & $\$ 1.368$ & $\$ 1.8$ & 76 & $\$ 5.0$ & 27 \\
\hline STI/HIV/AIDS & $\$ 2.695$ & $\$ 0.5$ & 539 & $\$ 9.9$ & 27 \\
\hline Basic research & $\$ 0.752$ & $\$ 0.1$ & 752 & $\$ 0.1$ & 752 \\
\hline Total & $\$ 5.268$ & $\$ 6.2$ & 85 & $\$ 20.2$ & 26 \\
\hline
\end{tabular}

Notes and Sources:

Donor targets were assumed to be one-third of totals needed except for adjusted STI/HIV/AIDS targets, where donor share is assumed to be two-thirds.

2004 donor expenditure figures are based on preliminary data from the Financial Resource Flows for Population Activities in 2004 Report from the Resource Flows Project (accessed at http://www.resourceflows.org/index.php/articles/c87/) and include the $\$ 5.268$ billion that could be attributed to an expenditure category of the $\$ 5.620$ billion total.

Donor targets for 2005 are from: UNAIDS (2005) and Speidel (2005). 
per client provided with contraceptives (Howell, 2006). With half of the 34 million U.S. women in need of contraceptive services reliant on public funding, an annual expenditure of about $\$ 3.5$ billion is needed (Sonfield, 2003). This can be compared to public outlays of $\$ 1.261$ billion for contraceptive services in 2001-about one-third of the total needed (Sonfield \& Gold, 2005).

\section{Addressing population: a neglected approach to environmental preservation}

Environmental advocates and conservation program planners generally understand the importance of population issues, but have often given them a lower priority than deserved. Reasons include lack of scientific expertise, the belief that tackling population issues is too controversial or unlikely to yield success, and a perceived absence of moral standing given the disproportionately high rates of consumption in developed countries. Prevention of unintended pregnancy is a strategy that, for most of the public, is not controversial, yet can have a substantial impact on reducing population growth and the concomitant pressures it places on the environment. The successful family planning programs found in many settings, as diverse as Thailand, Iran, and California, show that such programs are desired, feasible, and costeffective.

Environmental organizations can make an important contribution by educating their membership, policy makers, and the public about the need for global action to improve access to family planning both in the United States and worldwide. Environmental organizations can build and mobilize a base of grassroots activists to advocate for improved family planning and reproductive health policies and programs, and they can help raise public awareness about the links between population and environment.

Specific actions for environmental activism internationally include:

- Country-level advocacy to reduce restrictions on access to family planning information and services, including for young people and the unmarried,

- Advocacy for the financial and human resources necessary to strengthen family planning and related reproductive health services, including programs that address the HIV/AIDS epidemic,

- Supporting access to all methods of family planning including the safe abortion services that are essential to reproductive health and childbearing choices, and

- Advocacy for international development efforts such as education (especially for girls) that encourage slower population growth.

On the U.S. domestic front, specific actions by environmental activists should include:

- Outreach and education about how population growth affects the environment and quality of life,

- Advocacy and other efforts to help ensure universal access to sexuality information, education, and services, especially for young people, 
- Advocacy to ensure that all reproductive health policies and programs are based on scientific evidence, rather than ideological beliefs,

- Advocacy in support of universal access to affordable family planning programs, especially those that serve low-income populations and youth,

- Advocacy in support of universal and affordable access to abortion,

- Outreach and advocacy in support of an open and rational dialogue around U.S. immigration policies and programs.

Keeping in mind the significant impact of U.S. policies and funding in other countries, environmental activists can also help ensure that the United States has sound policies and contributes its fair share of funding for family planning programs in developing countries. The U.S. government should also be encouraged to ensure that, wherever possible, HIV/AIDS, family planning, and other reproductive health services are made available together or linked.

As worldwide awareness of environmental deterioration increases, the energy and efforts of the environmental community, working with media, decision makers, and the public, could have a profound impact on improving family planning and reproductive health policies and programs that benefit women, men, families, society, and the environment.

The population field needs increased commitment, appropriate policies, and adequate human and financial resources. If these conditions are fulfilled, population growth will slow, reproductive health will be improved, and the environment protected.

\section{References}

Abbasi-Shavazi, M. J. (2002). Recent changes and the future of fertility in Iran. Paper presented at: Expert group meeting on completing the fertility transition. Population Division, Department of Economic and Social Affairs, United Nations Secretariat; March 11-14, 2002; New York.

Alan Guttmacher Institute. (1999). Sharing responsibility: Women, society and abortion worldwide. New York: Alan Guttmacher Institute.

Assadourian, E. (2003). Economic growth inches up. In Worldwatch Institute (ed.), Vital signs 2003 (pp. 44-45). New York: W. W. Norton \& Company.

Bixby Center for Reproductive Health Research \& Policy, Department of Ob/Gyn and Reproductive Sciences, University of California San Francisco. (2005). Final evaluation report of family PACT. August 31, 2005. Available at: http://www.familypact.org/_resources/documents/051117_OFP\%20report_OK\%20to\%20print.pdf Accessed August 23, 2006.

Bongaarts, J. (1994). Population policy options in the developing world. Science, 263(5148), 771-776.

Braveman, P., Egerter, S., \& Marchi, K. (1999). The prevalence of low income among childbearing women in California: Implications for the private and public sectors. American Journal of Public Health, 89(6), 868-874.

Brindis, C., Amaral, G., Foster, D., \& Biggs, M. (2005). Cost-benefit analysis of the california family PACT program for CY 2002. January 2005. Available at: http://www.familypact.org/assests/ documents/Cost\%20Benefit\%20Final\%20Report\%20\%201-28-05.pdf Accessed August 23, 2006.

Brown, L. R. (2004). Outgrowing the earth: The food security challenge in an age of falling water tables and rising temperatures. W. W. Norton \& Company, Inc.

Camarota, S. A. (2004). Economy slowed, but immigration didn't: The foreign-born population, 2000 2004. Washington, DC: Center for Immigration Studies.

Camarota, S. A. (2005). Births to immigrants in America, 1970 to 2002. Washington, DC: Center for Immigration Studies. 
Carr, D., \& Khan, M. (2004). The unfinished agenda: Meeting the need for family planning in less developed countries. Washington, DC: Population Reference Bureau.

van Dalen, H. P., \& Reuser, M. (2005). Assessing size and structure of worldwide funds for population and AIDS activities. Netherlands Interdisciplinary Demographic Institute. Available at: http:// www.resourceflows.org/index.php/articles/c87/Accessed October 10, 2005.

Ehrlich, P. R., \& Ehrlich, A. H. (1990). The population explosion. New York: Simon and Schuster.

Ethelston, S., Bechtel, A., Chaya, N., Kantner, A., \& Vogel C. G. (2004). Progress \& promises: Trends in international assistance for reproductive health and population. Washington, DC: Population Action International.

Finer, L. B., \& Henshaw, S. K. (2006). Disparities in rates of unintended pregnancy in the United States, 1994 and 2001. Perspect Sex Reprod Health, 38(2), 90-96.

Foster, D. G., Biggs, M. A., \& Amaral, G., et al. (2006). Estimates of pregnancies averted through California's family planning waiver program in 2002. Perspect Sex Reprod Health, 38(3), 126-131.

Frost, J. J., Sonfield, A., Gold, R. B., \& Ahmed, F. H. (2006). Estimating the impact of serving new clients by expanding funding for title $X$. New York: Guttmacher Institute.

Green, C. P. (1992). The environment and population growth: Decade for action. Baltimore: Johns Hopkins University, Population Information Program. Series M, No. 10.

Hirschman, C., Tan, J. E., Chamratrithirong, A., \& Guest, P. (1994). The path to below replacement-level fertility in Thailand. International Family Planning Perspectives, 20(3), 82-87, 107.

Howell, M. (2006). Analysis provided by UCSF family PACT program support and evaluation: E-mail correspondence on October 10, 2006.

Kendall, H. (2005). World scientists' warning to humanity. Union of concerned scientists. Available at: http://www.ucsusa.org/ucs/about/page.cfm?pageID=1009 Accessed December 6, 2005.

Kent, M. M., \& Mather, M. (2002). What drives U.S. population growth? Washington, DC: Population Reference Bureau.

Levine, R., et al. (2006). Contraception. In D. Jamison, et al. (Eds.), Disease control priorities in developing countries (2nd ed.). Washington, DC: World Bank.

McDevitt, T. M. (2005). World population profile: 1998. US census bureau. Available at: http:// www.census.gov/ipc/prod/wp98/wp98.pdf Accessed October 7, 2005.

Millennium Ecosystem Assessment. (2005). Ecosystems and human well-being: Synthesis. Washington, DC: Island Press.

Munson, M., \& Sutton, P. (2004). Births, marriages, divorces, and deaths: provisional data for 2003. National vital statistics reports. June 10 2004;52(22).

Passel, J. S. (2006). The size and characteristics of the unauthorized migrant population in the U.S.: Estimates based on the March 2005 current population survey. Washington, DC: Pew Hispanic Center.

Perry, M. J., Mackun, P. J. (2005). Population change and distribution: 1990 to 2000. U.S. census bureau. Available at: http://www.census.gov/prod/2001pubs/c2kbr01-2.pdf Accessed December 9, 2005.

Population Division, Department of Economic and Social Affairs, United Nations. (2004). World population to 2300. New York: United Nations.

Population Division of the Department of Economic and Social Affairs of the United Nations Secretariat. (2005). World population prospects: The 2004 revision and world urbanization prospects: The 2003 revision. Available at: http://esa.un.org/unpp/Accessed June 20, 2005.

Population Reference Bureau. (2007a). 2005 World population data sheet. Available at: http:// www.prb.org/pdf05/05WorldDataSheet_Eng.pdf Accessed January 11, 2007.

Population Reference Bureau. (2005). Family planning worldwide: 2002 data sheet. Available at: http:// www.prb.org/pdf/FamPlanWorldwide_Eng.pdf Accessed December 14, 2005.

Population Reference Bureau. (2007b). 2006 World population data sheet. Available at: http:// www.prb.org/pdf06/06WorldDataSheet.pdf Accessed January 11, 2007.

Population summit of the world's scientific academies. (1993). Washington, DC: The National Academies Press.

Potts, M. (1997). Sex and the birth rate. Population and Development Review, 23(1), 1-39.

Rosenfield, A. G., Hemachudha, C., Asavasena, W., \& Varakamin, S. (1971). Thailand: Family planning activities 1968 to 1970. Studies in Family Planning, 2(9), 181-192.

Singh, S., Darroch, J. E., Vlassoff, M., \& Nadeau, J. (2003). Adding it up: The benefits of investing in sexual and reproductive health care. New York: Alan Guttmacher Institute.

Sonfield, A. (2003). Preventing unintended pregnancy: The need and the means. New York: Guttmacher Institute. 
Sonfield, A., \& Gold, R. B. (2005). Public funding for contraceptive, sterilization and abortion services, FY 1980-2001. New York: Guttmacher Institute.

Speidel, J. J. (2005). Population donor landscape analysis for review of Packard Foundation International Grantmaking in population, sexual and reproductive health and rights. The David and Lucile Packard Foundation. September 6, 2005. Available at: http://www.packard.org/assets/files/population/program\%20review/pop_rev_speidel_030606.pdf Accessed July 13, 2006.

State of California, Department of Finance, Demographic Research Unit. (1999). CPS 1997 age by sex by poverty level of persons (pp. 15-44). Sacramento, CA.

UNAIDS. (2005). Questions \& answers: International programmes, initiatives and funding issues. June 2005. Available at: http://www.unaids.org/html/pub/una-docs/q-a_i_en_pdf.pdf Accessed October $18,2005$.

UNFPA. (2005). Summary of the ICPD programme of action. United Nations department of public information. Available at: http://www.unfpa.org/icpd/summary.htm Accessed October 10, 2005.

UNFPA, UNAIDS, NIDI. (2004). Preliminary publication of the data to be published in the Financial Resources for Population Activities Report (FRFPAR). The Hague: Resource Flows Project.

United Nations. (2005). The flow of financial resources for assisting in the implementation of the programme of action of the international conference on population and development, report of the secretary-general to the 37th session of the commission on population and development. New York: United Nations.

United Nations Development Programme, United Nations Environment Programme, World Bank, World Resources Institute. (2002). A guide to world resources 2002-2004: Decisions for balance, voice, and power. Washington, DC: World Resources Institute.

United Nations, Department of Economic and Social Affairs, Population Division. (2005a). World population prospects: The 2004 revision, highlights. New York: United Nations.

United Nations Department of Economic and Social Affairs Population Division. (2005b). World contraceptive use 2003. Available at: http://www.un.org/esa/population/publications/contraceptive2003/WallChart_CP2003.pdf Accessed October 5, 2005.

U.S. Census Bureau, Population Division. (2007). Annual estimates of the population for the United States, regions, and states and for Puerto Rico: April 1, 2000 to July 1, 2006 (NST-EST2006-01). Available at: http://www.census.gov/popest/states/NST-ann-est.html Accessed January 15, 2007.

Vlassoff, M., Singh, S., Darroch, J. E., Carbone, E., \& Bernstein, S. (2004). Assessing costs and benefits of sexual and reproductive health interventions. New York: Alan Guttmacher Institute.

Wilson, E. O. (2002). The future of life. New York: Alfred A. Knopf.

World Bank. (2005). World development indicators. Available at: http://www.worldbank.org/data/ wdi2005/wditext/home.htm Accessed October 11, 2005.

World Resources Institute. (1998). World resources 1998-99. A guide to the global environment: Environmental change and human health. New York: Oxford University Press. 